\title{
EXCLUSION AND NETWORKS THE RESPONSIBILITIES OF THE ACTORS IN HUNGARIAN SPATIAL PLANNING FOR THE MITIGATION OF EXCLUSION
}

\author{
KRISZTINA JÁSZ \\ Centre for Regional Studies, Hungarian Academy of Sciences \\ Rákóczi str. 3, Kecskemét H-6000, Hungary \\ e-mail: jaszk@rkk.hu
}

\begin{abstract}
Recently, it has been claimed that spatial inequalities in Hungary had by far not reduced, but significantly increased since 1990. The inefficiency of Hungarian regional development in the reduction of spatial inequalities, in the past two decades has been caused by several different reasons. Functional deficiency of the local institutions of the regional development network is one of the most characteristic reasons, which led to this situation. Network members at the next planning turnover should be able to change the attitudes catalyse the changes necessary, being able to contribute to the realisation of a planning practice based on community development.
\end{abstract}

Keywords: spatial inequality, network, community development

\section{INTRODUCTION}

European, as well as Hungarian regional planning policies have come to a turning point referred by several EU and national documents, e. g. the report of Fabrizio Barca and colleagues or the pamphlets made by VÁTI Office for Spatial Planning and Evaluation, such as 'Quo Vadis Spatial Planning?'.

As a researcher of social exclusion and the local features of the Hungarian practice of regional planning, I consider the growing importance of policies concerning spatial inequalities and social inclusion as the most hopeful element of the critical remarks emerged recently. Both the Barca-Report and nation documents postulate clearly, that former ambitions for the mitigation of spatial inequalities had failed, as the difference between the various spatial units had been growing in Hungary as well as in the whole EU, instead of decreasing. Although the inequalities between regional GDPs have not risen significantly, a spectacular change can be seen in intra- 
regional diversities. Due to this tendency, the islands of exclusion have evolved even within spatial units with favourable socio-economic indicators. It is made clear by the documents referred above, that spatial equalisation had not been an adequate ambition even in EU policies, and the more impulsive concept of exclusion had become necessary regarding the features and seriousness of the problem. On the other hand, strengthening of partnership and networks-as an essential background for more effective interventions-as well as the dissemination of their good practices have been postulated as another central element of the critical documents.

The present study is aimed at a revision of the Hungarian practice of spatial planning, in the light of the above tendencies.

Soon at the starting point of any examination concerning the relationship between spatial planning and social exclusion, the lack of a single conceptual definition forms a great burden of the analysis.

Though each approach to be mentioned later reflects some important aspects of the problem, I should declare in advance, that I consider the most adequate those definitional endeavours reflecting the complete lack of social ties, beyond the weakening of employment positions and the disintegration from the world of labour. This motive is particularly interesting regarding our topic, as it highlights what a burden is formed by the lack of central personalities capable to generate the networks necessary for reintegration, and to communicate as representatives and media of those excluded with the local specialists from official networks. As a result of this feature, official actors of spatial planning networks have an enormous responsibility in the generation of projects contributing to the employment and social reintegration of those excluded, in a strong cooperation with the locals.

Pre-recently, hardly any good practices can be found in this field in the most backward micro regions of Hungary, being the focal points of exclusion.

Having delineated a short analysis of the theories of exclusion, I shall resume the way having been leading to the distortion of Hungarian spatial planning policies, as well as the functional anomalies of the different networks. Last but not least, I shall describe a planning practice suitable for a more effective dealing with both exclusion and the local level of partnership.

\section{SOCIOLOGICAL THEORIES ON POVERTY AND EXCLUSION}

As I have already stated above, there is a rich literature on poverty and exclusion as social features used often as synonyms. Due to size limits, I focus on theories based upon multidimensional approaches considering the integrative function of labour market as just one of the indicators to explain social exclusion.

Among the several researchers of exclusion, Robert Castel is particularly to be mentioned for the creation of the concept of disintegration with the meaning of the dissolution of social ties. According to Castel (Castel 1993), the process of 
disintegration can take place along two dimensions: those of the labour market and social-family ties. In his opinion, those having become unemployed and simultaneously isolated socially, can be found in the zone of exclusion.

The approach of Amartya Sen has shows great similarities with the theory of Castel. In his theoretical studies, Sen (Sen, 2003; 2004) puts a strong emphasis on the various stages of the process of exclusion. According to his theories, the position of individuals in the labour market plays a fundamental role in their career, as unemployment serves as the main sustainer of exclusion. Long-term unemployment can result in the loss of working skills, and in the same time, the dissolution of learning and adaptive skills. At the cognitive level, this process can lead to the loss of self-confidence and the capability of decision on the self. Disintegration from the community is an automatic result of the above mental and physiological processes. According to another empirical finding of Sen, minority groups are always the first affected by adverse trends on the labour market, catalysing intolerant, racist and exclusive attitudes at the macro level of contemporary European society.

Both of the above theories chosen subjectively and presented briefly, put a strong emphasis on the threats of the disintegration from social ties, as well as on the multidimensional character of deprivation within the issue of exclusion.

In the following chapter, the contribution of the wrong-headed regional development policies from the last 50 years to the deepening social exclusion is analysed.

\section{THE ROLE OF LOCAL DISADVANTAGES IN SOCIAL EXCLUSION}

The evolution of Hungarian society since the end of WWII has some features proving to be very difficult to be corrected, the extreme strengthening of traditional spatial inequalities being one of them (Szalai 2002). It is worth resuming the „contribution” of Hungarian economic and planning policies to the extreme polarisation of development by the different periods.

According to Nemes Nagy and Dövényi (Nemes Nagy and Dövényi 2003), four period of spatial processes are presented.

\section{ADAPTATION OF THE SOVIET MODEL (1948-1968)}

As a principal feature of this period, regional planning - not existing even as a partial policy—was substituted by the industrialisation of the countryside. Quantitative growth of material production was regarded as the main economical priority, dominated by the development of heavy industry. Investment into infrastructure, having an essential importance in the living standards of citizens, was paid little attention, the only achievement being the electrification of villages. Besides forced industrialisation, collectivisation of agriculture also took place in this period, both processes resulting in a significant internal migration from rural areas to the capital city and the centres of heavy industry, modifying the demographical composition of villages, 
as well as the social structure of the receiving cities adversely. Nevertheless, the full employment of the 1960s started an equalisation among the different regions.

\section{THE HUNGARIAN MODEL (1968-1982)}

This period was substantially affected by the change of the basic theories of economical governance, namely the introduction of indirect economical regulation instead of the former direct planning. Parallely, the system of values transmitted by the political sphere changed significantly, as consumption and quality of life emerged besides production.

This change was bolstered by numerous provisions as the programmes aiming the improvement in the living standards of the population, focused on infrastructural development. Due to the investments, a slow equalisation of incomes started at the regional level. By the mid-70s, however, resources devoted to an extensive development were narrowed, resulting in serious peripherisation processes within the settlement network, especially at the micro region level. Territorisation and the close of low-traffic railway lines formed the most important elements of the above process. To sum up, a robust differentiation at the micro region and local level hiding behind regional equalisation was the main feature of this period.

\section{THE CRISIS OF THE REGIME (1982-1989)}

The 1980s showed a further decline in development resources, though its consequences were not yet present in the whole country. Areas of mono-sectoral economy were affected the most seriously by the lack of resources. This period marks the formation of the present depressed areas, essentially important regarding social exclusion.

The enduring key role of state enterprises in the economy formed another agent of the crisis. Affected by the recession, these enterprises reacted with the displacement of their difficulties to the peripheries. Closing their rural sites was one of their typical means, often in such areas where the given factory had been the only significant local employer. Dismissal of commuting workers recruited mostly from internal and external peripheries formed another means of enterprise strategies. Although the development of backward areas transparent by that time, was postulated as by a 1985 decree, the lack of time and the necessary means encumbered its implementation.

\section{SPATIAL PROCESSES OF THE POST-COMMUNIST PERIOD}

Due to the dramatic changes of the early 1990s, the relative social equalities of the late communism declined soon, the difference between the upper and lower deciles of the population growing as never seen before. Poverty become a factor of local development perspectives (Dövényi 2003). Nearly 1.5 million of jobs ceased in Hungary, being the principal actor of the dramatic growth in temporary poverty.

However, the period since the collapse of the communist regime is not homogenous, its first half being dominated by decline and crisis, while equalisation 
and stabilisation tendencies at the national level emerged in the second half. Due to the decline since 2006, caused by the global economic recession, the social conflicts of the early 90 s can be to face by the country soon. Regarding spatial processes, there have never been satisfactory conditions, as the processes guaranteeing a lasting spatial equalisation have failed to start.

Due to the great spatial inequalities of development, new kinds of social conflicts can be witnessed. By now, development opportunities of settlements are clearly determined by their spatial position (Dövényi 2003).

The extreme focus on infrastructural investments by the last two decades' development policies has escalated the adverse effects of the above, let's say deterministic disadvantages. Moreover, a great deal of paternalism has been associated to the inadequate priorities, the management of social conflicts being substituted by the various development fundings distributed as quasi aids, manifested by renovation and maintenance works rather than by investments aimed at a complex development (Horkay 2009). During the last two decades, long-term sustainable strategies reflecting to the unique spatial features and demands have been constantly lacking from the Hungarian practice of spatial planning.

A slight modification in the spatial approach has been resulted by EU accession, accentuating the role of micro region level besides regions. By the decree No. 1059/2003 EC, the member states were mandated to create their micro regions, a responsibility fulfilled by Hungary, too. A number of ministries-including Prime Minister's Office, Ministry of Agriculture and Rural Development and Ministry of Self-Governments and Spatial Planning-founded various networks of specialists at this level, under different names as village managers, rural development managers, micro region manager etc. By 2006, even the relevant decision- makers admitted these networks to fulfil parallel tasks with significant overlaps (Beck 2006). The situation was complicated by the successive governments often creating new networks at the same time they dismissed or transformed the existing ones. Furthermore, the micro regions also tended to employ spatial development managers from their budgets, creating a new network in the system.

As a capitalisation of the above negative experiences, and for the sake of cutting expenses and increasing efficiency, the Government of Hungary decided to found a Coordination Network of Micro Regions in 2007, integrating the previous networks of the institutions of spatial planning ${ }^{1}$. Considering the selection criteria of the 300 specialists, however, it is clear that the new network will not be able to fulfil the principal aims motivating its foundation, one of these aims being the effective contribution to the development of the 33 most unfavourable micro regions.

Networking competence has the following elements: communication skills, trust, strategic skills and the ability of compromises for cooperation. In spite of the above requirements, general knowledge on EU and its funding system formed the most professional criteria of the selection, showing no intention to examine the attitudes,

\footnotetext{
1 The village and rural development manager networks with their parallelities have survived.
} 
social skills and experimental knowledge of the candidates. There are no signs of intention by the ministry responsible for the Coordination Network of Micro Regions to manage the distrust factors hampering cooperation at the local level. Embeddedness of the Network is also encumbered by the-mostly opposition-local governments regarding the specialists appointed as ,soldiers” of the Government. The effective communication is hampered by similar political conflicts between the different networks settled at the micro region level. As long as this conflict far from professional matters has not been managed by the every time government, no significant improvement will be achieved at the work of human networks as catalysts of local partnerships.

What is then to do for these networks to become a means of development for the population of backward areas, instead of being a means of division?

In accordance with other Hungarian experts, I represent the idea that a new concept of human beings, as well as a new practice of spatial planning are necessary for the creation of social and spatial cohesion. Implementation of a so-called creative spatial planning is needed (Horkay 2009), focused on the locality, its local actors being capable to play a catalysing role, in the same time producing samples of good practice. From a planning point of view, these elements are reflected the most transparently by communal, or community development based planning. Why is it so?

As a result of failed political decisions, funding regimes and the planning practice associated to them, cooperation with local communities has an insufficient representation at the creation of planning documents. Due to this fact, there is a lack of real feedbacks of the various planning documents produced in the last two decades towards the most affected local communities, making these people feel again justly ignored, let down and exploited (Faludi 2004). The majority of small settlements covering 6 to 8 percents of the country's whole territory do not have the sufficient ways to postulate their discontent. Professionalism of planning alone, however, is still inadequate to improve the conditions of those living in backward micro regions. Regarding planning as a common learning process was one of the key elements of the sporadic successful projects by now-common learning of decision-makers, specialists and people using the services and the results of investments.

Lack of the socialisation of planning and its products was not the only feature of the failed planning practice. The adverse effects of unemployment, spatial position, low levels of education and lack of central personalities were escalated by the favourisation of steel and concrete investments instead of human development. Regarding programmes for the integration to the labour market as the sole means of development proved to be another failed concept, as the proportion of those excluded did not drop significantly by these programmes unless they were complemented by sectoral and inter-sectoral initiatives for social integration. 


\section{PHASE NO. 0 OF PLANNING}

Due to the above facts, a thorough preparation process is essential for the planning, especially in the most backward micro regions. At phase No. 0, inclusion and capacitation of local communities should be prepared, making them able to move with self-confidence in a space unknown for the by this time. Inclusion to the creation of future projects of those most affected forms a key factor of the success and sustainability of these projects.

In case the local communities can be removed from their apathy as a result of a common conflict management strategy, the state of distrust described above will resolve. This means the strengthening of the still existing traces of self-confidence mostly diminished by disadvantages and exclusion, rather than improving trust towards every time decision-makers at the national level.

It has already been justified by a number of successful community development initiatives from Hungary, that more effective and creative investments can be achieved by the active participation of the local community in planning than by a centralised planning ignoring the local population. In the best case, a planning process based on community development results in the formation of new local communities, particularly if new central personalities grow and become the main initiatives of transition at the micro region level.

Taking the above statements into consideration, I find the so-called phase No. 0 of planning to have a great significance, in spite of the fact that it is often omitted from planning by ignorance. It is essential to devote the necessary amount of time for the creation of a forum for a creative process, serving as an opportunity for local communities to express their ideas and opinions, as well as to understand the basic issues concerning development.

\section{BASIC PRINCIPLES OF PLANNING}

- the aims should be postulated by the inclusion of the widest possible circle of those affected;

- the inclusion should cover the whole process of planning, implementation and evaluation, not only the preparation phase;

- local and micro region interests should be taken into account while planning;

- the planning process itself should be also planned;

- the constant openness of planning should be guaranteed.

Advantages of planning based on the inclusion of local communities:

- a clear vision of the future can be created, providing security, strength and motivation not only for local and micro region leaders but also for local communities;

- a more balanced cooperation within settlements and micro regions can grow by the exploration of demands and needs;

- individual problems can become community concerns, getting community solutions;

- investments more appropriate to local demands can emerge in the future; 
- the planning process can be interiorised as a common learning process by its participants, contributing to individual and community development fundamentally.

As settlements coping with serious financial problems are certainly unable to pay the professionals needed for community development, network members at the next planning turnover should be able to change the attitudes catalyse the changes necessary, being able to contribute to the realisation of a planning practice based on community development. Of course, this is a time- and energy-intensive process, but the present crisis may even help to accelerate this kind of reform, by waking up people to the importance of networks and partnerships. The same process is catalysed by the intentions to the modification of EU cohesion policies.

\section{REFERENCES}

Beck, M. (2006), “A területi hálózatok szerepe 2007-töl.<http://www.tancsicsalapitvany.hu>

Castel R. (1993), A nélkülözéstől a kivetettségig- a "kiilleszkedés pokoljárása”, Esély, 3, 3-23.

Dövényi, Z. (2003), A településrendszer fejlődése és sajátosságai, in: Magyarország társadalmi-gazdasági földrajza, Perczel Gy.(ed.) ELTE Eötvös Kiadó, Budapest, $521-528$.

Barca, F. (2009), Towards a territorial social agenda for the European Union. $<$ www.report_barca_v0605.pdf >

Faludi, E. (2004), Kistelepülési elmélkedések, <www.kispad.org>

Horkay, N. (2009), A Magyar területfejlesztési politika legfontosabb kihívásai és megújulásának lehetséges irányai, < www.rkk.hu>

Horkay, N. (2009), Quo Vadis területfejlesztés?—unpublished document.

Nemes Nagy, J. (2003), Regionális folyamatok, in: Magyarország társadalmi-gazdasági földrajza. Perczel Gy. (ed.), ELTE Eötvös Kiadó, Budapest, 565-569.

Szalai, J. (2002), A társadalmi kirekesztődés egyes kérdései az ezredforduló Magyarországán, Szociológiai Szemle, 2/4, 34-51.

Sen, A. (2003), A társadalmi kirekesztés: fogalom, alkalmazás és vizsgálat I, Esély, $6,3-22$.

Sen, A. (2004), A társadalmi kirekesztés: fogalom, alkalmazás és vizsgálat II, Esély, $1,3-25$. 